\title{
Medieval Fortress of the Lowland Type in Virovitica - Reflection on Archaeological Excavations in the City Park in Virovitica by 2017
}

\author{
Silvija Salajic* \\ Virovitica City Museum, Croatia
}

*Corresponding Author: Silvija Salajic, Virovitica City Museum, Croatia

\begin{abstract}
Virovitica is a town in the north of Croatia that has a rich history. In the Middle Ages it was the possession of the Hungarian queens. Here King Bela IV wrote an important charter for Zagreb. The Medieval fortress of the lowland type in Virovitica is located in the center of the town. Here King Bela IV wrote an important charter for Zagreb. The Medieval fortress of the lowland type in Virovitica is located in the center of the town.

In the 19th century it was destroyed and in its place Pejačević Count built a castle. During the rebuilding of the city park, archaeological excavations of the tower base, the west entrance and the bridge pilot began. The text shows the results of probing excavations. They will eventually lead to a systematic excavation within the castle reconstruction.
\end{abstract}

Keywords: Medieval Lowland Fortress of the Lowland Fort, Tower Foundation, Bridge Pilots, Western Entrance, Pejačević Castle

\section{INTRODUCTION}

The medieval fortress of the lowland type is an important part of Virovitica's history, as evidenced by its size and accommodation in the city center. It is visible only in the configuration of the soil with plateau and moat around it because it was completely destroyed and its place was occupied by the Pejačević Castle at the beginning of the 19th century. Although it was preserved only in its foundations, the fortress had a strong influence on the development of the city, and to this day, it is a part of the social and cultural life of Virovitica. It is less known that the medieval fortress in Virovitica dictated the appearance and development of the city of which radially expanded (Horvat A. 1958: 161-169, Fischer 1996: 100-103).

The fort was archeologically interesting with the first excavation of the 1991. During the works on the expansion of the city's basin, there was a southern entrance to the fort of the bridge pilots. Wood stakes are found in the moat as water protection. ${ }^{1}$ When digging for the seat bases, a 40-m long tunnel was found, which stretched in the direction of north -south below the plateau and merged into the tunnel network. The network of tunnels, as well as the canals, was an integral part of a very well-built defensive system of the late middle ages of lowland fotress. ${ }^{2}$

The fortress changed its appearance during its long existence. ${ }^{3}$ Namely, at the time when the Koloman Charter was written, the medieval Virovitica -Wereucha is already a large settlement, latin-magna villa. At the same time the palace (castrum) is mentioned (Adamček 1986: 114). Probably it was a considerably smaller fort, made of wood on solid foundations. After the use of the pile in particular falls under the Ottoman rule, when it was found on the border of the two empires, Austrian and Ottoman had a look we can see on the preserved views of the 17th century. At the time of his termination, he was used as a witness of past time within the domain of the nobility.

\footnotetext{
${ }^{1}$ ( Salajić 2008: 16-17)

${ }^{2}$ Drago Doppler has made a remarkable effort to record, compile and save from oblivion the irrigation system of the lowland fortress in Virovitica as an attachment titled "Story of Virovitica Bridges, City on Water" published in 2000 in "Pusa" no. 10, p. 34-38. Due to the importance of the data, based solely on the memory and courtesy of editor GoranGazdek, we have repeated the text in the catalog of the exhibition "Medieval fortress of the lowland type in Virovitica" 2008. This first catalog of fortresses with a group of authors, curators of the Museum and associates has united a small number of so far known data about the Virovitica fort.

${ }^{3}$ We did not know the first fortress, but it certainly did exist.
} 
Today it is located in a protected area of the archaeological zone, as a monument of immovable cultural heritage. In recent times, we have greatly enriched the knowledge of the medieval fortress of the lowland type in Virovitica.

The systematic archaeological excavations of the forts started in the framework of the reconstruction of the city park, thanks to regular financing by the Ministry of Culture. Until that time the cluttered West entrance was excavated in 1998. and 1999. After 5-6 years of interruption, excavations took place in the position of the medieval bridge, i.e. wooden pilots in front of the Entrance. At the same time, excavation of the foundation of the northeastern tower on the plateau began.

\section{THE WeSTERn ENTRANCE TO THE FORT}

Historical data on the West entrance to Virovitica fort are very modest. They are mostly limited to a drawing showing a brick wall with a semicircular end in front of which a coat of arms held by two herolds is placed. The famous drawing of the old Virovitica town of E. Kramberger was published in Vienac in 1880. The presence of the coat of arms, as well as the damaged heads of herolds, can be seen in an old photo from the photo gallery of the City Museum in Virovitica. Herolds with a coat of arms were available in the city park until the 40s of the 20th century. Namely, Count Pejačević, after constructing the Castle and planting the park in the early 19th century, in front of the entrance to the fort, previously closed it, set up there his family coat of arms with medieval guardians-herolds.

Missing was the exact location of the stumped entrance, where we used the memories of Virovitica ${ }^{4}$. When excavating the West Gate we found a well-preserved stone composition, with herolds, coats of arms and stone arches on the plateau. ${ }^{5}$ The western entrance, as the place where it was most threatened by the danger of attacking the enemy, was preserved in the width of 10 meters. It is made of brick in the upper part and chiseled stone in the lower part. It dates at the time of construction of the fort in the $15^{\text {th }}$ century.

The area of the former western entrance, $10 \mathrm{~m}$ long, $3 \mathrm{~m}$ wide and $2,50 \mathrm{~m}$ in height, was buried with building construction waste. Two partition walls of brick and several layers of plaster were found by releasing and cleaning the space. At the level of the flooring, canalization was found in the west -east direction, with a fall in the trench. The side walls referred to a room that had a barrel vault but also a separate entrance. In all likelihood it was the lowest room of the square entrance tower as a basement. ${ }^{6}$ Higher floors, one of them had access to the plateau, i.e. the courtyard of the fort, not preserved, and by comparison we can assume its appearance. ${ }^{7}$ The Western entrance to the fort is, besides a mobile bridge and with the water in the moat secured with a solid object in front of it. ${ }^{8}$

\section{Wooden Pilots OF The Medieval BRIDGe}

After the herolds and the coat of arms were removed from the find site, their restoration was carried out and the continuation of excavations in front of the West Gate was made possible. Bridge pilots were found with deep digging up to $3 \mathrm{~m}$. In the following years more pilots were found that were properly arranged and grouped. With excavation only their distribution and preservation were established. ${ }^{9}$

Their southern boundary was established, and excavation in the trench has brought to light and transversal beams. ${ }^{10}$

In the layer above the pilots of bridge there was a thicker layer of construction waste with a lot of findings from the late middle and new age. The most frequent finds are pieces of ceramic and lesser glass vessels, sections of iron objects and larger quantities of animal bones. The porcelain, majolica, glazed pottery is found in the layer of the new era.

\footnotetext{
${ }^{4}$ We are especially grateful to Drago Doppler and Ante Ivanušić, lovers of the cultural heritage of our town, who, according to very good memory, correctly identified the site of the entrance to the fort and herold, covered with earth, in the western part of the city park.

${ }^{5}$ The position of the herolds holding the coat of arms is identical to the 19th century E. Kramberger's drawing.

${ }^{6}$ A similar entrance tower is in Bedemgrad near Našice (Horvat 2014: 79).

${ }^{7}$ The fortress in Đurđevac, which has been preserved in its entirety, has the same interior of the entrance as it would be in Virovitica that it was not demolished for the purpose of building the baroque Castle.

${ }^{8}$ The lesson is that in the future the fort should be observed considerably wider than the city park space.

${ }^{9}$ Excavation 2005-2010.

${ }^{10}$ The results of the analysis of the C-14 method of two different piles of pilot piles of wood excavated in 2008 at the RuđerBošković Institute in Zagreb showed the data of 1320-1340 AD and 1390-1450 AD.).
} 
The sludge layer in which pilots are found contains rich flora and fauna. It is a cultural, intact layer, so it needs special attention. The flotation and the obligatory presence of zooarheologists and archeobotanists must be used in the field.

\section{THE FOUNDATION OF THE Si TOWER}

The cause of excavation was that count Pejačević used two towers, one square, the other round, one as a grating, another as a chapel (Š́citaroci 1998: 320). ${ }^{11}$ Historical sources have not given the location of the tower. Then we were helped by local artist Dragutin Tari with his drawing of fortress and church in Virovitica in the 18th century. So excavation on the northern towers began. After the family chapel, in the frame of Castle Pejačević, the chapel of Mary Helpers became public at the end of the 18th century. There are processions in honor of St. Florian (the protector of the fire) and the St.Emigdije (patron of the earthquake) (Cvekan 1977: 129). The preserved valuable inventory from the chapel stored in the Franciscan monastery in Virovitica is a subject of constant professional consideration and supplement (Kulej 2008: 89-91; Kulej 2017: 5, 6).

The $16 \mathrm{~m}$ diameter round tower, which later housed a chapel, is preserved only in its foundations. It is made of crushed stone and bricks, linked by plaster. At regular intervals, grooves of vertically-laid beams, which were used for construction, are visible. With the excavation internal wall which is also well preserved, the foundation width of $4.60 \mathrm{~m}$ was established. The massive object of the circular ground plan is walled out of two parts, as evidenced by the joints of the joints but also the traces of beams and boards.

The excavation mainly, the outer wall of the wall is carried out since 2004 and is today excavated to a depth of $3.50-4.00 \mathrm{~m}$. A small number of finds date back to the 15th century, although slightly lower layers point to red painted ceramic from the 14th century. ${ }^{12}$ The location and shape of the fortress point to its early medieval existence in the 9th century, and similar sites tell us that we can expect the same fortress from the bronze age. ${ }^{13}$ Its foundations and ramparts are amplified, as described in the 17th century travel books (Sabolić 2008: 53).

Based on the tower is the most interesting western part. Here is a part of a 40 -cm-high wall of the foundation. It shows the characteristics of proper masonry of alternating rows of brick and carved stone, linked by plaster. In this part, a tunnel and a secret passage of bo th masonry with bricks have been found. In front of the opening, made as a secret passage, in the case of an emergency, was found the beams and holes of the stakes arranged in a semicircle at a depth of $2.40 \mathrm{~m}$. Unfortunately, due to the narrower excavation area, it was not possible to dug up the whole object, which will surely have to be corrected in the future.

\section{FORTRESS AND FirST OWNERS}

The first written evidence of the construction of the fort comes from the 15th century, namely from 1453. to 1474.(Adamček 1986: 113). It is also the time of the fort that comes to light by archaeological digging. The novelty is that it is no longer a royal property but private. The owners of the fortress at that time were the brothers Marczaly (Adamček 1986: 113). Afterwards he changed several owners: Pethold Edderbach, Nikola Čupor Moslavački, Nikola and Jakob Banffy Donjolendavski (Adamček 1986: 114). Later the fortress in Virovitica was under Ottoman rule from 1552 to 1684 , when it had many changes. ${ }^{14}$ From the time of belonging to the Ottoman Empire, the drawings and descriptions of the fortifications come from (Sabolic 2008: 53-64). These are important documents, especially for the reconstruction of the fort. But its final appearance will only be established through complete archaeological digging.

\footnotetext{
${ }^{11}$ Dr. Sc. Mladen and dr.sc.BojanaŠćitaroci used Rudolf Horvat's manuscript in the book. This and other useful data for the medieval history of Virovitica is contained in the book Rudolf Horvat, History of Virovitica published by MaticaHrvatska, the branch of Virovitica in cooperation with the City Museum.

${ }^{12}$ It is necessary to complete the excavation of the outer shelf of the tower to the level where there are no findings.

${ }^{13}$ For this kind of excavation at higher depths there are suggestions for the way of working, as well as for the attractive presentation of the tower's foundation by architect AzreSuljić.

${ }^{14}$ Its foundations and ramparts are amplified, as described in the 17th century travel books (Sabolić 2008: 53).
} 
So far, well-known graphics of the fort (8 pieces) join another two. VladoKovačević from Virovitica has found another graphic at the University Library in Zagreb and informed the Museum. ${ }^{15}$ It is an incentive for further historical and cultural historical research of medieval Virovitica.

\section{Fortress AND PEJAČEVIĆI}

The fort was part of the Countess Pejačević family when it was no longer in use. Prior to the construction of the castle at the beginning of the 19th century they used some of its parts, such as two towers and the Western entrance. Conservatory works at the Castle in 2004 testified that the construction of the castle started on the firm foundations of the medieval fortress. ${ }^{16}$ After the construction of the Castle, the entrance to the west side of the park was used as a decoration in the garden. ${ }^{17}$

\section{FORTRESS AND CITY}

Virovitica's geographic position increased the strategic importance of the fort, which was particularly pronounced in the middle Ages. Then the proximity of Hungary and its historical circumstances determined its development. Unfortunately, in that period, archeology is not sufficiently represented. Archaeological excavation has not yet found a fortress from the 13th century. Then Virovitica was the property of the Hungarian queens. ${ }^{18}$ (Virovitica possessed a parish church as well medieval market town with two monasteries, Dominican and Franciscan monasteries, with their respective churches. Only Franciscans have remained to this day. (Andrić 2006: 46; Adamček1986: 113) The Baroque church of St. Rock with the monastery was built on foundations the medieval church of St. Mary. Two Romanesque columns have been preserved in the interior of the Baroque church. (Horvat A. 1986: 351). Recently, by archaeological excavation, a square apse of a medieval church was found, along with the eastern foundation of today's church of St. Rok. The skeletal graves date back to the 13th century.The works on the waterproofing of the church of St.Rok of the 18th century, in its eastern part, found the foundations of older buildings and particularly important skeletal burials. The graves are located at the base of the stone and contain medieval coins (frizatic) dating back to the 13th century. The archeologically immobile find proves that the much smaller franciscan church of St. Mary and monastery also existed in the middle ages, located under the present baroque church of St. Rok. (Salajić 2017: 90, 91). There is also evidence for the cemetery around the parish church of St. Kuzma and Damjanand indications for the church and monastery of the dominican order. There are records about the hospital of St. Nicholas and perhaps the existence of a women's monastery. (Andric 2006: 44). Let's hope soon for the archeological-historical research on the medieval past of Virovitica, which will be adequately presented at that time.

Within the new permanent exhibition of the City Museum of Virovitica in there constructed castle of Pejačević, a significant place will become a fortress because it has played a significant role in the history of the city. Depending on the results of archaeological excavations and the conservator's suggestions, some of its parts will be exhibited on the spot in the renewed fort of Count Pejačević as a permanent reminder of the Virovitica archaeological and historical heritage.

\section{CONCLUSION}

Today, the medieval lowland fortress is only visible in the terrain configuration. One can see the plateau and the moat around it, now without water. Namely, Count Pejačević built the castle at the same place and planted a park. Yet he used some parts of the fortress, a town as a chapel. These parts of the fort are precisely the ones preserved and covered by excavation. The base of the massive, round towers was excavated at a depth of $3.50-4.00 \mathrm{~m}$. The west entrance revealed the lower part of the entrance. Wooden bridge pilots show a proper layout. Ceramic archaeological finds date back to the 15th century. At that time the owners of the fort were Marczaly brothers. We hope that these initial excavations of the largest fortress of the lowland type in continental Croatia will help in the complete

\footnotetext{
15 Original, graphic (carved wood) of Virovitica is located in the work of Ivan Lucić "De regnoDalmatiae et Croatiae" issued in 1666. ZoltanOrši, the director of the Drava Museum in Barcsa, also gave important information on the end of 17th century by Andreas NunzerVirovitica graphic, which is in the possession of their Museum.

${ }^{16}$ Conservators from Urbosd.o.o from Osijek, owner of the architect MilkoPuncer, found in 2004. the gothic window in the ground floor of the Castle in the west of the entrance.

${ }^{17}$ It is not known the place where Pejačević's coat of arms was after the fire in 1871 but is well preserved and his detailed description is thus possible (Luvčenjak 2006: 128, 129).

${ }^{18}$ Let us remind you that Virovitica at that time was the seat of the least county in Slavonia.
} 
excavation of the fortress. After the reconstruction of the Castle some parts of the fort will be presented in situ.

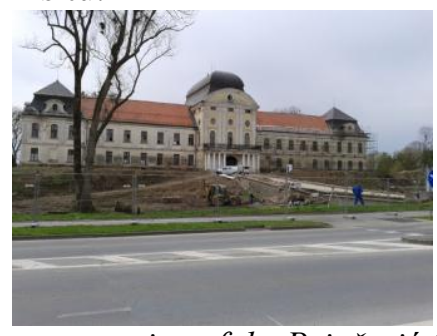

Works on reconstruction of the Pejačević Castle

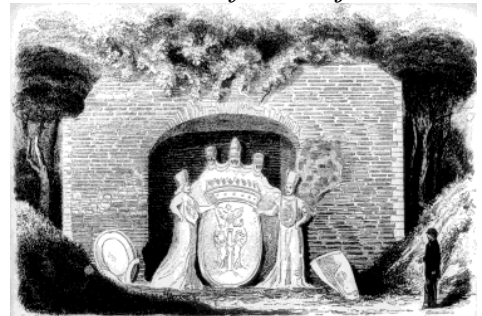

Drawing with coat count Pejačević and her olds infront of the medieval wall

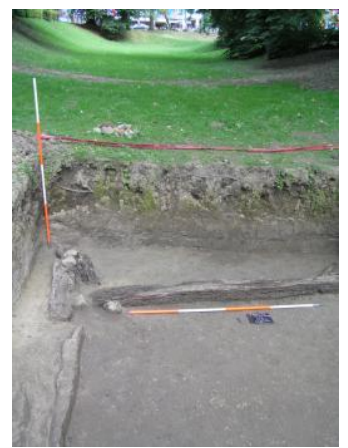

Pilots of the bridge and the beam in the trench around the fort

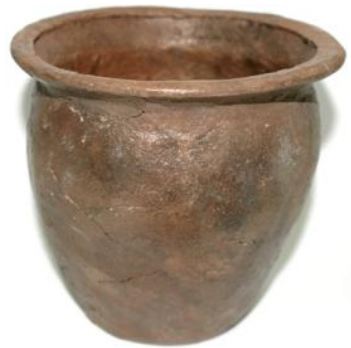

Potteryvesselfromthe 15th century.

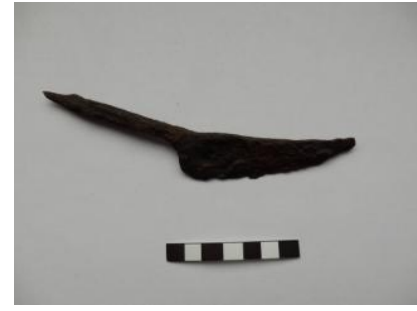

Knife

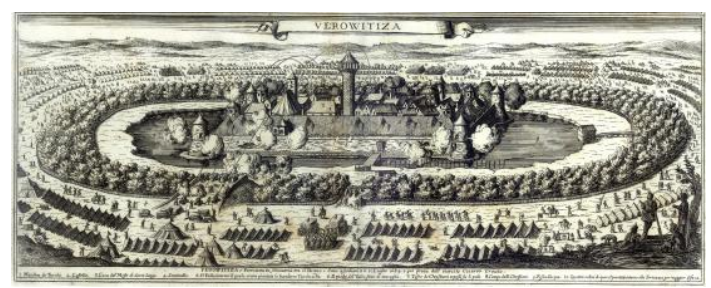

The picture of castle Virovitica with general Leslie and austrian army arround the castle in Virovitica in 1684

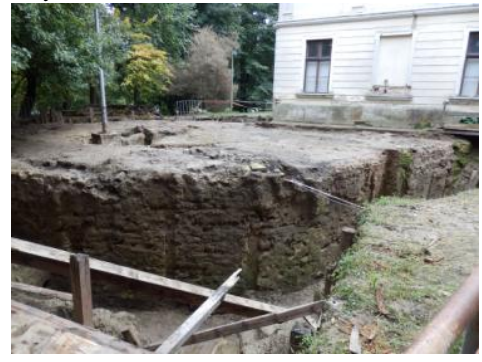

The foundation of north-east tower

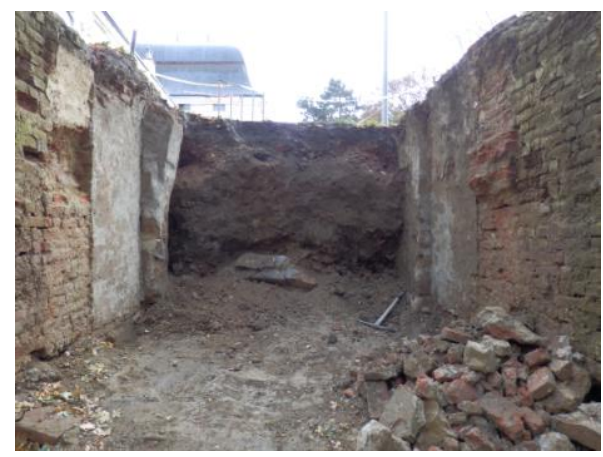

Archeological excavation of the West Gate to the fort

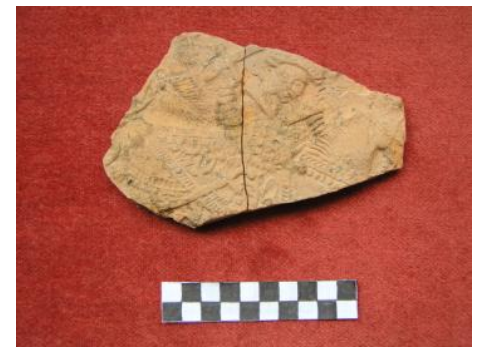

Pottery depicting an Ottoman soldier

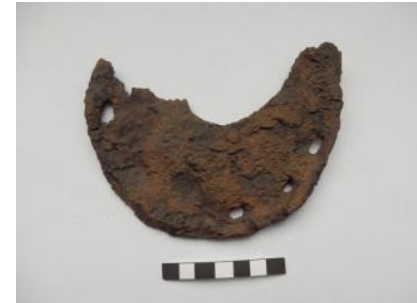

Horseshoe

\section{REFERENCES}

[1] Adamček,J.(1986).Virovitica and Virovitica County in the Middle Ages. Virovitica anthology 12341984.113-126.

[2] Andrić,S.(2006).Franciscans in medieval Virovitica.725 years of Friars in Virovitica.43-56.

[3] Cvekan,P.(1977).Virovitica and Franciscans.

[4] Čimin,R.(2008).Ceramic finds from the fort of Čanjevo. The Fortress Čanjevo- Research 2003-2007.121191. 
[5] Čimin,R.(2008).Metal finds from the fort of Čanjevo. The Fortress Čanjevo- Research 2003-2007.197235.

[6] Doppler,D.(2000).The Story of Virovitica Bridges. City on the Water.VirovitičkaPusa.34.-38.

[7] Doppler,D.(2008).A city on the water. Medieval fortress of the lowland type in Virovitica. Exhibition catalog.75-80.

[8] Fischer, M. (1996).Urban sequence tags .Virovitica-Selected Topics.100-103. Miljenka Fischer, Urban sequence tags .Virovitica-Selected Topics, Virovitica 1996, p. 100-103.

[9] Horvat,A.(1958).About the urban core of Virovitica, Bulletin of the Institute of Fine Arts.No 3.161-169.

[10] Horvat,A.(1986).About cultural monuments in Virovitica region. Virovitica anthology 1234-1984.351356.

[11] Horvat,R.(2001).History of the City of Virovitica.

[12] Horvat, Z.(2008).Review of the last excavation of the medieval fortress in Virovitica. Heritage. Periodical the City Museum of Virovitica, God II, No. 2.50-58.

[13] Horvat, Z.(2014). Burgology.

[14] Ivanković,G.M.(2006).View of Virovitica in the view map: A.D.1683Campaign on the Danube. 725 years of Friars in Virovitica.157-161.

[15] Kulej,M.(2008).Inventory of the Chapel of Mary Helpers in Virovitica Fortress.Medieval fortress of the lowland type in Virovitica. Exhibition catalog.87-92.

[16] Kulej,M.(2017).Inventory of the Chapel of the Mary Helpers in the Viroviticafort.Homeland.No.33.4-8.

[17] Luvčenjak,S.(2006).Family Pejačević and Virovitica.725 years of Franciscan in Virovitica.119-139.

[18] Mažuran,I.(1986). Virovitica and its surroundings during Ottoman rule (1552-1684). Virovitica anthology 1234-1984.127-156.

[19] Radić,M. and Bojčić,Z.(2004).Medieval Town ofRužica.

[20] Sabolić,D.(2006).From Fortress to Pejačević Castle.725 years of Friars in Virovitica.101-119.

[21] Sabolić,D.(2008).Virovitica (Fortress) in the descriptions and views of the 17th and $18^{\text {th }}$ centuries. Medieval fortress of the lowland type in Virovitica. Exhibition catalog.53-64.

[22] Salajić,S.(2008).Review of Archaeological Excavations1991-2008.Medieval fortress of the lowland type in Virovitica. Exhibition catalog.4. - 37.

[23] Salajić,S.(2010).Medieval fortress of the lowland type in Virovitica. Journal of the Zagreb Archaeological Museum. 3s.vol.XLIII.355-379.

[24] Salajić,S.(2014).Medieval fortress of the lowland type in Virovitica 2.Exhibition catalog.

[25] Salajić,S.(2017).Archeological Discovery of the Church of St. Marija in Virovitica.Homeland.No.33.90-91.

[26] Šćitaroci,M.O.andBojanićŠćitaroci,B.O.(1998).Castles and Parks in Slavonia. Mladen ObadŠćitaroci and Bojana Bojanić ObadŠćitaroci, Castles and Parks in Slavonia, Zagreb 1998.

[27] Šćitaroci,M.O. and Šćitaroci,B.O.(1996).City Park in Virovitica, Space.scholarly journal of architecture and urban planning. Vol 4.157-174.

[28] Škiljan,I.(2007).Veliki Tabor in the light of archaeological discoveries. Exhibition catalog.35-122

\section{AUTHOR'S BIOGRAPHY}

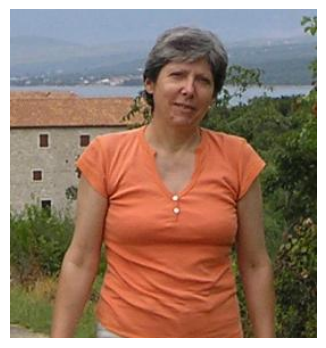

After studying a single-faceted archeology at the Faculty of Philosophy in Zagreb, Silvija Salajic worked for several years at the Brodsko Posavlja Museum in SlavonskiBrod. There he learned much about the work of a curator and loved the Museum and the Plain in Slavonia. She returned to the hometown of Virovitica and there, as the first curator, the archeologist began to develop archeology. Now, when he is at the end of his trip, he can say that he has been able to interest the experts and the local community for the archeology of the Virovitica region. It is her wish that this path continues and that in continental Croatia also archeology is a tourist destination.

Citation: Silvija Salajic. "Medieval Fortress of the Lowland Type in Virovitica - Reflection on Archaeological Excavations in the City Park in Virovitica by 2017."International Journal of Humanities Social Sciences and Education (IJHSSE), vol 5, no. 7, 2018, pp. 132-142. doi: http://dx.doi.org/10.20431/23490381.0507015 .

Copyright: () 2018 Authors. This is an open-access article distributed under the terms of the Creative Commons Attribution License, which permits unrestricted use, distribution, and reproduction in any medium, provided the original author and source are credited. 